\title{
RANCANG BANGUN SISTEM INFORMASI MANAJEMEN INVENTORI BERBASIS WEB DAN ANDROID
}

\author{
Nindian Puspa Dewi, Ridho Abdi Fadlillah \\ Program Studi Informatika, Universitas Madura \\ Jl. Raya Panglegur KM. 3,5 Tlanakan, Pamekasan \\ nindianpdeunira.ac.id, ridhoabdifadlillah@gmail.com
}

\begin{abstract}
In trading companies the use of applications aims to increase productivity, both in obtaining, processing, and using data for the benefit of the company. The Rutaka shop is a micro, small and medium enterprise that is engaged in the sale of building materials, electrical equipment, and households. Inventory recording is done manually and does not yet have an integrated system between sales and warehouse. Purchases of goods are recorded in a logbook which allows the record to be lost or damaged. The sales department must go directly to the warehouse to ensure that the goods to be sold are still available. The researcher applies the moving average forecasting method which is used to determine the number of items to be ordered or purchased. The data that will be used in the forecasting is data on goods going out in the warehouse for the last three months. The results show that the use of this application can increase the effectiveness of recording orders, returning goods, incoming and outgoing goods, knowing the stock of goods available in the warehouse.
\end{abstract}

Keywords - android, inventory, moving average, forecasting, web.

\begin{abstract}
Abstrak - Pada perusahaan dagang penggunaan aplikasi bertujuan untuk meningkatkan produktivitas, baik dalam memperoleh, mengolah, dan menggunakan data untuk kepentingan perusahaan. Toko Rutaka merupakan usaha mikro kecil dan menengah yang bergerak dibidang penjualan bahan bangunan, alat-alat listrik, dan rumah tangga. Pencatatan persediaan barang dilakukan secara manual dan belum memiliki sistem yang terintegrasi antara bagian penjualan dan gudang. Pembelian barang dicatat pada buku catatan yang memungkinkan catatan hilang atau rusak. Bagian penjualan harus turun langsung ke gudang untuk memastikan barang yang akan dijual masih tersedia. Peneliti menerapkan metode peramalan moving average yang digunakan untuk mengetahui jumlah barang yang akan di pesan atau beli. Data yang akan digunakan dalam peramalan tersebut yaitu data barang keluar pada gudang selama tiga bulan terakhir. Hasil penelitian menunjukkan bahwa penggunaan aplikasi ini dapat meningkatkan efektivitas dalam pencatatan pemesanan barang, retur barang, barang keluar dan masuk, mengetahui stok barang yang tersedia di gudang.
\end{abstract}

Kata Kunci - android, inventori, moving average, peramalan, web.

\section{PENDAHULUAN}

Di era saat ini, sudah menjadi hal yang biasa jika perusahaan membutuhkan sistem yang terkomputerisasi untuk memudahkan karyawan dalam mengelola data dan melaporkannya kepada pimpinan [1] misalnya perusahaan yang bergerak di bidang perdagangan. Salah satu perusahaan yang membutuhkan keberadaan sistem informasi salah satunya adalah perusahaan dagang. Sesuai dengan namanya, perusahaan dagang adalah perusahaan yang memperjualbelikan barang dagang [2]. Pada perusahaan dagang penggunaan aplikasi bertujuan untuk meningkatkan produktivitas, baik dalam memperoleh, mengolah, dan menggunakan data untuk kepentingan perusahaan misalnya membantu pencatatan dan pengelolaan data persediaan barang sehingga perusahaan dapat mengetahui persediaan barang yang masih tersedia dalam gudang. Persediaan dapat diartikan sebagai persediaan barang yang disimpan pada tempat penyimpanan atau gudang yang akan digunakan atau dijual dimasa yang akan datang. Persediaan terbagi menjadi tiga bagian yaitu persediaan bahan baku, setengah jadi, dan barang jadi.
Bahan baku dan bahan setengah jadi akan diproses atau diolah terlebih dahulu untuk dijadikan suatu produk sedangkan persediaan barang akan disimpan pada tempan penyimpanan sebelum didistribusikan. Jadi perusahaan yang bergerak dibidang dagang akan memiliki persediaan [3].

Toko Rutaka merupakan usaha mikro kecil dan menengah (UKM) yang bergerak dibidang penjualan bahan bangunan, alat-alat listrik, dan rumah tangga. Pencatatan persediaan barang pada toko ini masih dilakukan secara manual dan belum memiliki sistem yang terintegrasi dengan baik antara bagian penjualan dan gudang sehingga pihak toko tidak dapat mengetahui secara pasti jumlah barang yang ada dalam gudang. Proses pembelian barang dicatat pada buku catatan yang memungkinkan catatan tersebut hilang atau rusak. Dalam catatan juga tidak selalu menghitung stok barang setiap ada penjualan atau barang yang rusak sehingga tidak layak jual. Karena itulah untuk memastikan stok, bagian penjualan harus turun langsung ke gudang untuk memastikan barang yang akan dijual masih tersedia. Ketidakjelasan stok barang ini juga mengakibatkan terjadinya penumpukan stok barang sehingga penggunaan ruang gudang 
kurang efesien. Penumpukan ini karena pembelian barang tidak didasarkan pada kebutuhan dan estimasi kebutuhan terhadap barang tersebut.

Melihat dari permasalahan ini maka perlu dibuat sebuah sistem informasi manajemen inventori yang dapat melakukan pencatatan keluar dan masuknya barang dari gudang, termasuk melakukan pencatatan terhadapat kondisi barang yang rusak dan masuk dalam stock opname. Selain itu, untuk menghindari terjadinya penumpukan stok, perlu adanya tambahan peramalan pembelian/pemesanan barang kepada supplier dengan melihat hasil penjualan pada bulanbulan sebelumnya. Dalam penelitian ini akan digunakan metode peramalan moving average untuk menentukan jumlah barang pada pemesanan barang. Rata-rata bergerak (Moving Average) adalah suatu cara yang digunakan untuk memprediksi suatu kejadian di masa depan dengan menggunakan datadata yang sudah terjadi dalam kurun waktu tertentu dan mencari nilai rata-rata dari data tersebut [4]. Metode ini cocok digunakan untuk melakukan peramalan data yang bersifat stabil dan tidak berfluktuasi secara tajam. Hal ini sesuai dengan jenis barang yang dijual di Toko Rukata yang tingkat penjualannya nyaris stabil tanpa melihat trend dan musim [5].

Penelitian tentang sistem informasi inventori telah banyak dilakukan sebelumnya antara lain, Perancangan Sistem Informasi Inventory PT. ABC [6], Sistem Informasi Inventori Gudang Untuk Mengontrol Persediaan Barang Pada Gudang dengan studi kasus di PT. Alaisys Sidoarjo [7], Perancangan Aplikasi Easy Inventory untuk Peningkatan Efisiensi Inventory Umkm Kota Batam [8] dan ada juga yang berbasis mobile seperti Aplikasi Manajemen Inventory Berbasis Mobile [9] dan Pengembangan sistem informasi inventory berbasis web dan mobile pada Perusahaan Transitco [10]. Sedangkan penelitian tentang peramalan yang menggunakan rata-rata data di beberapa bulan sebelumnya, antara lain Peramalan harga bahan-bahan proyek dengan menggunakan Metode Least Square [11], Penerapan Metode Moving Average dan Exponential Smoothing pada Peramalan Produksi Industri Garmen [4] dan Perbandingan Peramalan Penjualan Produk Aknil PT.Sunthi Sepuri Menggunakan Metode Single Moving Average dan Single Exponential Smooting [5].

Sistem informasi manajemen inventori pada penelitian ini akan dibuat dengan berbasis web dan mobile. Dikarenakan perbedaan platform dari kedua aplikasi tersebut maka perlu dibangun juga server yang terhubung langsung dengan database yang digunakan untuk mengolah dan menyimpan data selain itu menyediakan layanan RESTFul web services. REST merupakan salah satu layanan yang disediakan oleh web service yang digunakan untuk komunikasi data melalui protocol Hypertext Transfer Protocol [12]. Web service adalah suatu perangkat lunak yang diciptakan untuk membantu komunikasi antar mesin melalui jaringan [13]. Aplikasi mengakses URL (Uniform Resource Locators) untuk mendapatkan sumber data yang diinginkan pada server. Dengan menggunakan layanan RESTFul ini sumber daya yang terdapat pada server dapat diakses oleh berbagai platform.

Kelebihan dari sistem informasi manajemen inventori lainnya, sistem informasi manajamen inventori ini menambahkan peramalan pembelian/pemesanan barang kepada pemasok dengan menggunakan Metode Moving Average. Dengan begitu, selain dapat digunakan untuk mengetahui aliran keluar masuknya barang, sistem informasi ini juga dapat membantu pihak perusahaan/toko untuk mengontrol stok barang di toko dengan memberikan saran jumlah pembelian/pemesanan barang sesuai dengan hasil penjualan di beberapa bulan sebelumnya. Dalam implementasinya juga dibuat sesuai dengan fitur yang dibutuhkan dalam membangun sistem informasi inventori sesuai dengan analisa dan perancangan sistem inventori pada penelitian sebelumnya [14].

\section{METODE PENELITIAN}

Sistem Informasi ini dirancang dan dikembangkan dengan Metode Agile Software Development jenis Extreme Programming (XP) [9], [15], sedangkan untuk metode yang digunakan untuk peramalan stok adalah menggunakan Metode Moving Average.

Metode pengembangan dengan Extreme Programming (XP) meliputi perencanaan (planning), desain sistem (design), pembuatan program (coding) dan ujicoba (testing).

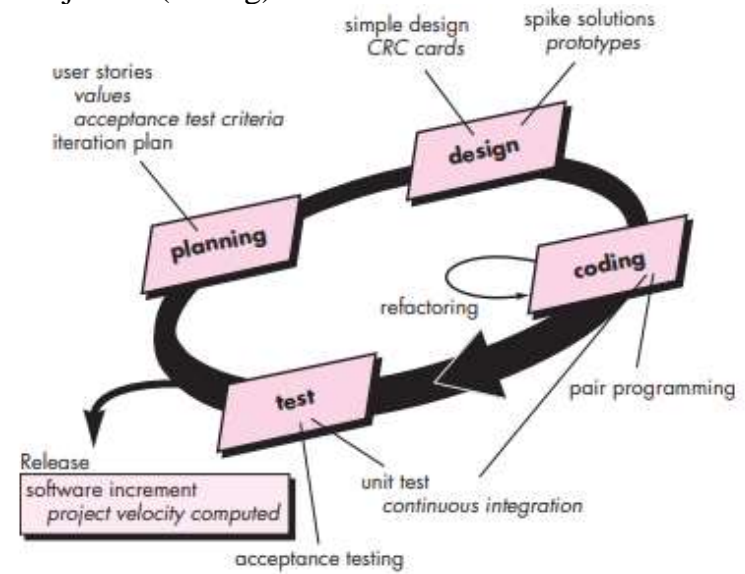

Gambar 1. Ilustrasi Proses Extreme Programming

(XP)

Perencanaan dilakukan dengan melakukan pengumpulan data untuk memperoleh informasi yang dibutuhkan dalam mendesain aplikasi. Pengumpulan data dilakukan dengan melakukan pengamatan langsung/observasi dan wawancara. Pengamatan dilakukan di awal pelaksanaan penelitiaan dengan melakukan kunjungan langsung ke lokasi penelitian dengan tujuan mendapatkan informasi yang 
dibutuhkan untuk dijadikan objek penelitian (Toko Rutaka). Pengamatan ini dilakukan untuk mengetahui proses yang ada khususnya pada bagian gudang. Hasil dari pengamatan ini adalah barang yang dijual adalah bahan bangunan, alat listrik, dan alat rumah tangga, sistem pencatatan barang keluar dan masuk masih ditulis pada buku. Dari kegiatan ini juga diketahui bahwa data stok barang tidak dapat di cek secara realtime dan tidak adanya pemisahan kondisi baik dan rusak. Toko ini juga memiliki 4 gudang untuk menyimpan barang, sehingga menambah sulitnya untuk mengetahui jumlah stok barang dengan cepat dan tepat.

Setelah dilakukan pengumpulan data, selanjutnya dilakukan analisis sistem bertujuan untuk mendefinisikan dan menggambarkan kebutuhan sistem dari aplikasi sistem informasi manajemen inventori. Analisis sistem dilakukan setelah semua data yang dibutuhkan sudah didapatkan untuk kemudian di analisa. Analisis sistem ini dapat terbagi menjadi 2 yaitu Analisis pengguna dan analisis input. Dalam aplikasi yang akan dibuat terdapat 1 pengguna yaitu kepala gudang sebagai admin dari inventori yang bertugas untuk mengelola semua aktivitas dalam sistem. Analisis input pada sistem dapat dilihat pada Tabel 1 dibawah ini:

Tabel 1. Analisis Pengguna

\begin{tabular}{ll}
\hline Pengguna & Keterangan \\
\hline Kepala & Create, Read, Update, Delete (CRUD)
\end{tabular}

Gudang Kelola kategori dan subkategori

Kelola barang

Kelola stock opname

Kelola barang masuk dan barang keluar

Kelola gudang

Kelola pemasok

Kelola pesanan barang

Kelola retur barang

Desain sistem dibuat dengan menggunakan unified modelling language (UML) [16]. Dalam hal ini diagram yang digunakan adalah usecase diagram dan entity relationship (ERD) [17]. Gambar 2 menunjukkan usecase diagram aplikasi inventori yang akan dibuat.

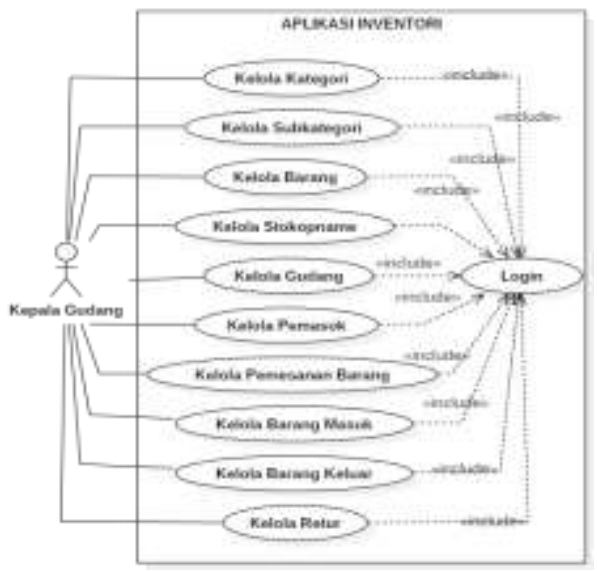

Gambar 2. Use Case Diagram
Kelola kategori adalah kegiatan untuk melakukan manajemen kategori pada aplikasi seperti kategori bahan bangunan, alat rumah tangga, dan alat listrik. Kelola sub kategori, digunakan pengguna untuk mengelola sub kategori. Sub kategori tersebut misalnya kabel, saklar, dan stop kontak. Kelola barang digunakan untuk mencatat semua data barang. Sedangkan pada proses kelola stock opname, pengguna dapat mengelola stock opname pada aplikasi. Kelola stock opname digunakan untuk mencatat kondisi barang misalnya baik atau rusak. Pada proses kelola pemesanan barang, pihak toko dalam melakukan pencatatan pemesanan barang terhadap supplier yang datanya tercatat dalam sistem. Jika barang datang maka dimasukkan sebagai barang masuk dan dicatat juga di gudang mana barang tersebut di simpan. Sebaliknya jika barang diambil dari gudang maka dicatat sebagai barang keluar. Kelola retur digunakan untuk mencatat adanya retur barang setelah dilakukan pengecekan saat barang pesanan telah diterima dan ditemukan barang yang rusak.

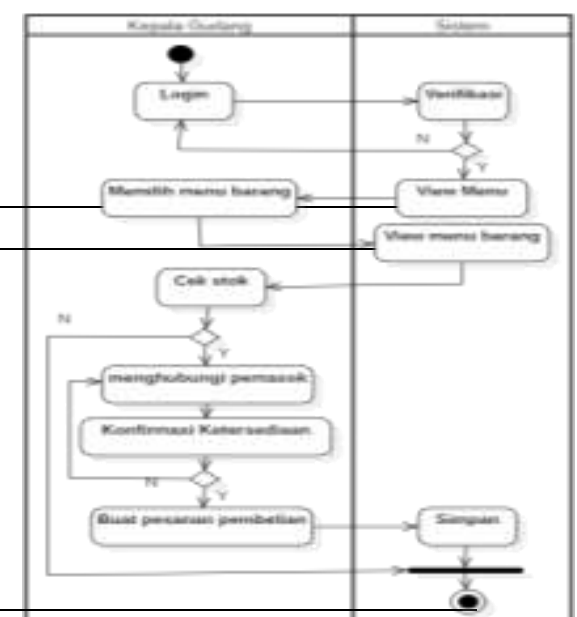

Gambar 3. Activity Diagram Pemesanan Barang

Desain sistem selanjutnya adalah activity diagram. Activity diagram ditunjukkan pada Gambar 3. Untuk menggunakan aplikasi, kepala gudang harus melakukan login terlebih dahulu pada sistem dan sistem akan memverifikasi data login tersebut. Jika login berhasil maka sistem akan menampilkan halaman menu tetapi jika tidak berhasil maka sistem tetap menampilkan halaman login. Kepala gudang memilih menu barang untuk melakukan pengecekan ketersediaan barang pada gudang dan sistem menampilkan halaman barang. Jika terdapat stok barang yang hampir habis atau habis maka kepala gudang menghubungi pemasok melalui telepon untuk mengkonfirmasi ketersediaan barang yang akan dipesan pada pemasok. Jika tersedia maka kepala gudang membuat pesanan pembelian barang dan menyimpan data pesanan tersebut pada sistem.

Pada Gambar 4 activity diagram penerimaan barang atau barang masuk. Activity diagram ini menjelaskan bahwa Kepala gudang melakukan login pada sistem, sistem akan memverifikasi data login 
tersebut. Jika login berhasil maka sistem akan menampilkan halaman menu tetapi jika tidak berhasil maka sistem tetap menampilkan halaman login. Kepala gudang memilih menu barang masuk dan sistem menampilkan halaman barang masuk. Kepala gudang mencari data pesanan untuk mengetahui detail dari pesanan tersebut dan melakukan pengecekan terhadap barang pesanan yang akan diterima dengan data pesanan. Jika barang pesanan sesuai dengan data pesanan maka data pesanan tersebut akan dikonfirmasi barang diterima dan data pesanan akan disimpan pada sistem.

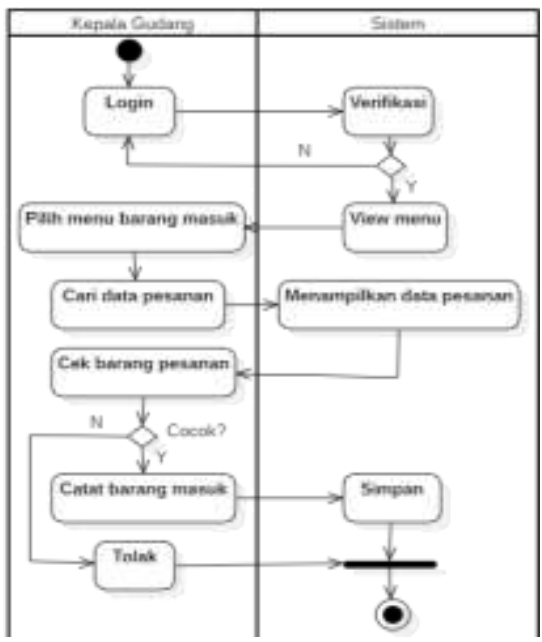

Gambar 4. Activity Diagram Penerimaan Barang

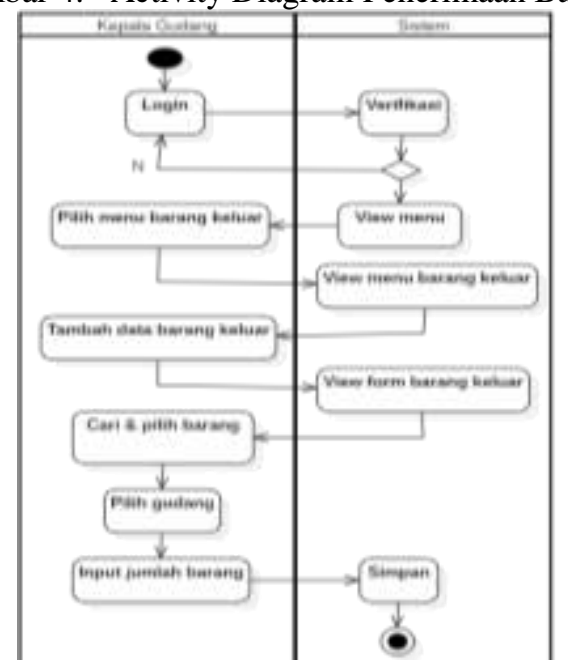

Gambar 5. Activity Diagram Barang Keluar

Gambar 5 menunjukkan activity diagram barang keluar. Gambar 5 menjelaskan bahwa Kepala gudang melakukan login pada sistem, sistem akan memverifikasi data login tersebut. Jika login berhasil maka sistem akan menampilkan halaman menu tetapi jika tidak berhasil maka sistem tetap menampilkan halaman login. Kepala gudang memilih menu barang keluar untuk menambahkan data barang keluar dan sistem menampilkan halaman barang keluar. Pada formulir barang keluar Kepala gudang mencari data barang dan menginputkan jumlah barang keluar. Data barang keluar akan disimpan di sistem.
Jika barang yang dikirim tidak sesuai dengan pesanan, maka kepala gudang dapat melakukan return pembelian dan mencatatnya dalam sistem. Pada formulir retur barang Kepala gudang memilih data pesanan secara otomatis sistem akan menampilkan data pesanan tersebut kemudian inputkan jumlah barang yang akan di retur dan jika terdapat barang yang tidak diretur pada data pesanan tersebut maka hapus data barang tersebut. Gambar 6 menunjukkan activity diagram retur barang.

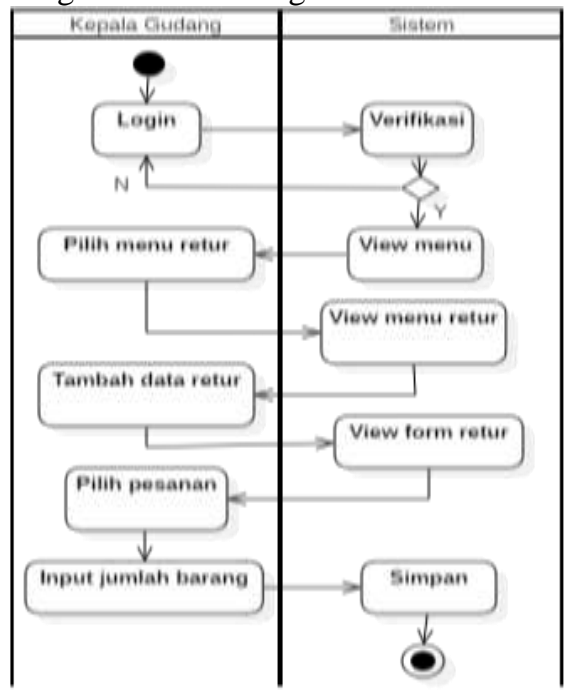

Gambar 6. Activity Diagram Retur Barang

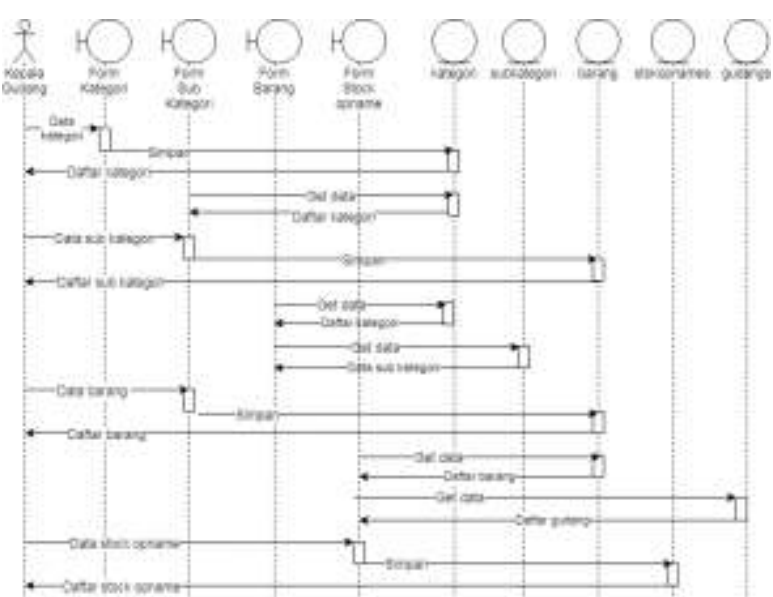

Gambar 7. Sequence Diagram Barang

Perancangan sistem selanjutnya adalah sequence diagram. Gambar 7 menunjukkan sequence diagram data barang yang terdiri dari beberapa proses, yaitu kelola kategori, kelola sub kategori, kelola barang, dan stock opname. Pada proses kelola kategori, pengguna mengisi data kategori berupa nama kategori pada form kategori. Data tersebut disimpan pada tabel kategori dan sistem akan menampilkan daftar kategori yang sudah diinputkan. Pada proses kelola sub kategori, ketika pengguna membuka form sub kategori secara tidak langsung pengguna juga melakukan request ke sistem untuk mengambil data kategori. Pengguna mengisi data sub kategori berupa nama kategori dan nama sub kategori pada form sub kategori. Data tersebut disimpan pada tabel sub kategori dan sistem 
akan menampilkan daftar sub kategori yang sudah diinputkan. Pada proses kelola barang, ketika pengguna membuka form barang secara tidak langsung pengguna juga melakukan request ke sistem untuk mengambil data kategori dan sub kategori. Pengguna mengisi data barang berupa kode atau barcode, kategori, sub kategori, nama, satuan, harga jual, dan harga beli. Data tersebut disimpan pada tabel barang dan sistem akan menampilkan daftar barang yang sudah diinputkan. Pada proses kelola stock opname, ketika pengguna membuka form stock opname maka akan dikirim request ke sistem untuk mengambil data gudang dan barang. Pengguna mengisi data stock opname berupa barang dan jumlah barang rusak. Data tersebut disimpan pada tabel stokopnames dan sistem akan menampilkan daftar stock opname yang sudah diinputkan.

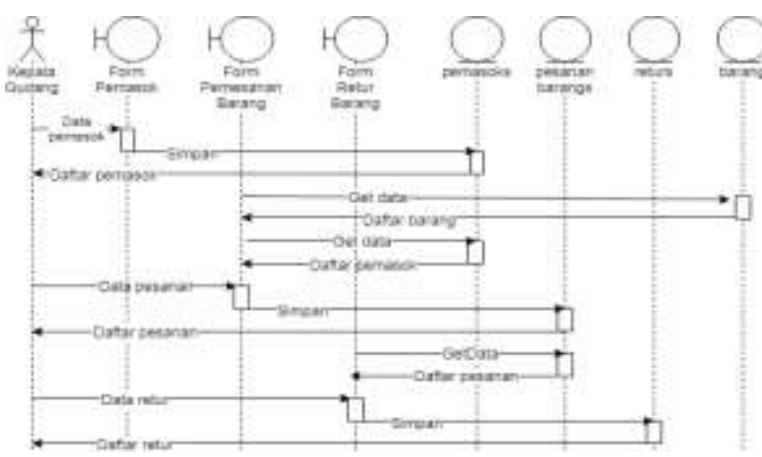

Gambar 8. Sequence Diagram Pemesanan Barang

Untuk sequence diagram pemesanan barang ditunjukkan pada Gambar 8. Ada beberapa proses yang ditunjukkan yaitu proses kelola pemasok, kelola pemesanan barang, dan kelola retur barang. Pada proses kelola pemasok, pengguna mengisi data pemasok berupa nama, alamat, email, dan nomor telepon pada form pemasok. Data tersebut disimpan pada tabel pemasoks dan sistem akan menampilkan daftar pemasok yang sudah diinputkan. Pada proses kelola pemesanan barang, ketika pengguna membuka form pesanan maka dikirim request ke sistem untuk mengambil data barang dan pemasok. Pengguna mengisi data pesanan berupa tanggal, pemasok, barang, jumlah barang, biaya pengiriman, dan potongan pesanan pada form pesanan. Data tersebut disimpan pada tabel pesanan barang dan sistem akan menampilkan daftar pesanan yang sudah diinputkan. Pada proses kelola retur barang, ketika pengguna membuka form retur secara tidak langsung pengguna juga melakukan request ke sistem untuk mengambil data pesanan. Pengguna mengisi data pesanan berupa tanggal, pemasok, barang, dan jumlah barang form retur. Data tersebut disimpan pada tabel returs dan sistem akan menampilkan daftar retur yang sudah diinputkan.

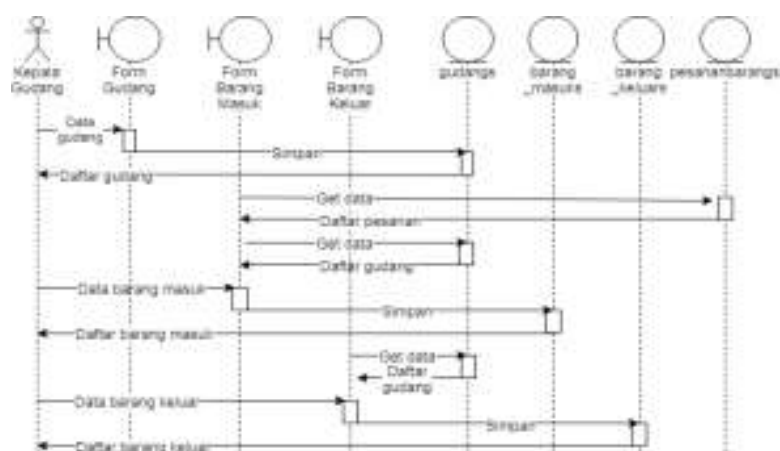

Gambar 9. Sequence Diagram Keluar/Masuk Barang

Selanjutnya adalah sequence diagram keluar/masuk barang yang ditunjukkan pada Gambar 9. Pada proses kelola barang masuk, ketika pengguna membuka form barang masuk sistem akan menampilkan data gudang dan pesanan. Pengguna mengisi data barang masuk berupa tanggal, pesanan, dan gudang pada form barang masuk. Data tersebut disimpan pada tabel barang_masuks dan sistem akan menampilkan daftar barang masuk yang sudah diinputkan. Pada proses kelola barang keluar, ketika pengguna membuka form barang keluar sistem akan mengambil data gudang dan data barang. Pengguna mengisi data barang keluar berupa tanggal, barang, dan gudang pada form barang keluar. Data tersebut disimpan pada tabel barang_keluars dan sistem akan menampilkan daftar barang keluar yang sudah diinputkan. Pada proses kelola gudang, pengguna mengisi data gudang berupa nama, gudang pada form gudang. Data tersebut disimpan pada tabel gudangs dan sistem akan menampilkan daftar gudang yang sudah diinputkan.

Setelah dibuat sequence diagram maka akan diketahui tabel yang dibutuhkan untuk membat aplikasi ini. Gambar 10 menunjukkan rancangan basis data yang dibuat.

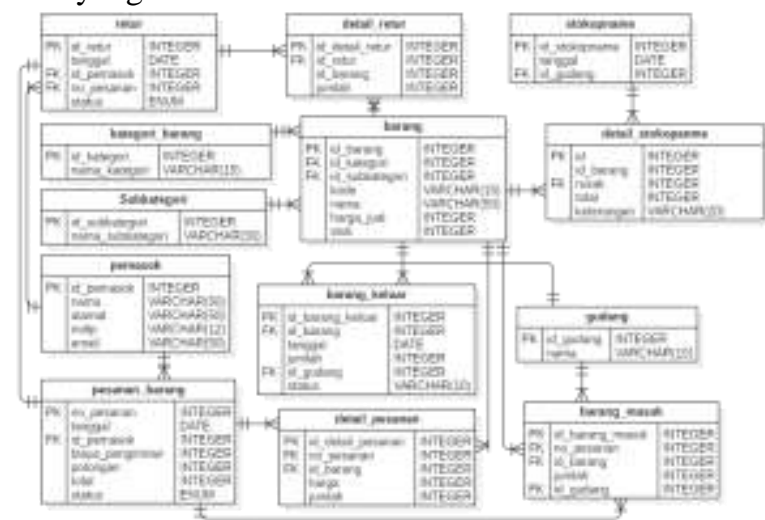

Gambar 10. Rancangan Basis Data

Seperti yang telah dijelaskan di bagian pendahuluan, sistem informasi manajemen inventori ini juga dilengkapi dengan fitur peramalan/forecasting untuk memberikan estimasi berapa jumlah barang yang akan dibeli sesuai dengan data hasil penjualan di bulan-bulan sebelumnya. Metode penelitian atau peramalan yang akan digunakan adalah Metode 
Moving Average yang ditunjukkan pada persamaan (1) berikut dengan menggunakan data 3 bulanan.

$\mathbf{F}_{t+1}=\frac{\sum_{t=t}^{t-N+1} X_{\mathrm{t}}}{N}=\frac{\mathrm{X}_{\mathrm{t}}+\mathrm{X}_{\mathrm{t}-1}+\cdots+\mathrm{X}_{\mathrm{t}-\mathrm{N}+1}}{N}$

Dimana :

$\mathrm{X}_{\mathrm{t}} \quad$ : Data Pengamatan Periode $\mathrm{t}$

N : Jumlah Deret Waktu Yang Digunakan

$\mathrm{F}_{\mathrm{t}+1} \quad$ : Nilai Prakiraan Periode $\mathrm{t}+1$ (Berikutnya)

\section{HASIL DAN PEMBAHASAN}

Setelah dilakukan perancangan sistem, maka selanjutnya dilakukan implementasi sistem.

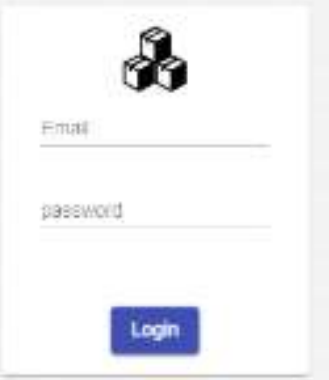

Gambar 11. Halaman Login

Gambar 11 menunjukkan halaman login digunakan untuk login ke sistem dengan cara menginputkan email dan password. Output yang dihasilkan berupa kondisi login sukses atau gagal sebelum masuk ke menu utama sistem [18][19].
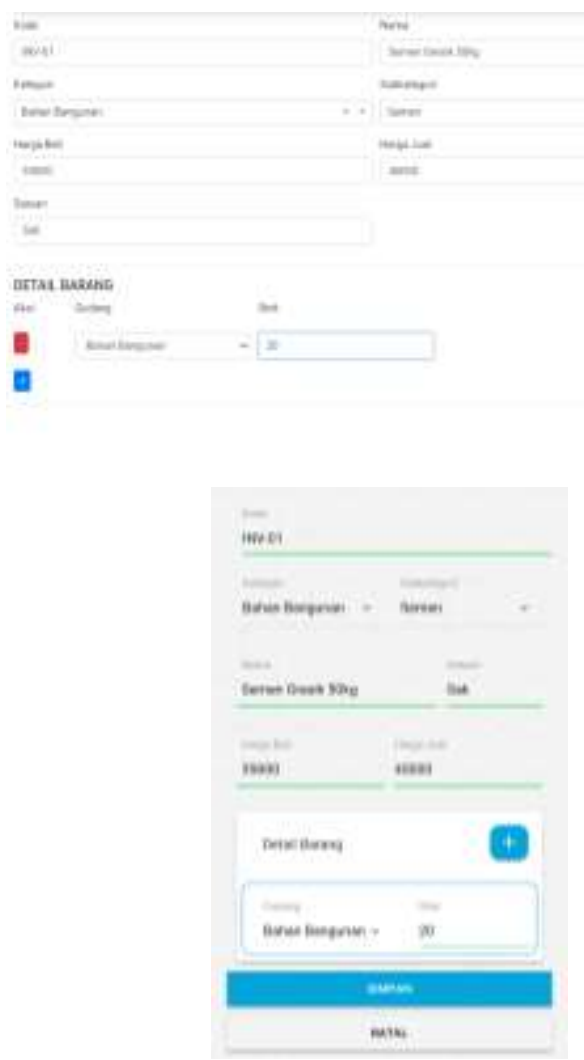

Gambar 12. Halaman Barang Berbasis Web dan Android
Gambar 12 menunjukkan halaman barang, pengguna mengisi data barang berupa kode, nama, kategori, sub kategori, harga beli, harga jual, satuan, dan detail barang [14][18]. Kode barang harus unik. Detail barang diperbolehkan tidak diisi. Detail barang diisi ketika mencatat barang yang sudah ada digudang. Data detail barang berupa jumlah stok dan nama gudang. Halaman barang dapat memudahkan kepala gudang maupun pemilik toko jika sewaktu-waktu ingin mengetahui detail barang, khususnya jumlah stok barang di gudang [14]. Dengan begitu inventarisasi barang yang ada di gudang menjadi lebih jelas dan rapi.
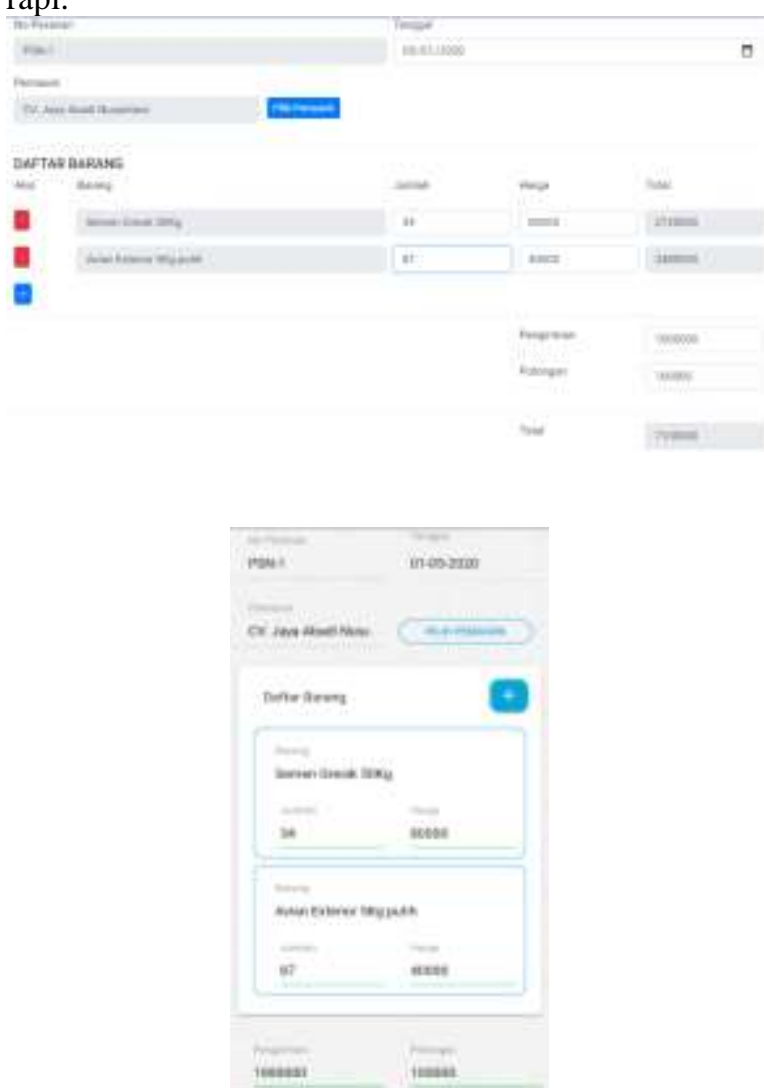

Gambar 13. Halaman Pemesanan Berbasis Web dan Android

Selanjutnya Gambar 13 menunjukkan halaman pemesanan barang pada supplier. Pada halaman pemesanan barang pengguna mengisi data pesanan berupa tanggal, pemasok, barang yang dipesanan, jumlah barang yang dipesan, biaya pengiriman, dan potongan harga. Ketika pengguna memilih barang yang akan dipesan maka jumlah barang pesanan secara otomatis akan terisi yang merupakan hasil dari peramalan dengan menggunakan metode moving average [4]. Proses peramalan ini dilakukan secara otomatis yang dilakukan oleh sistem secara otomatis. Jumlah barang yang dipesan dapat dijadikan bahan pengambilan keputusan jumlah pemesanan barang sehingga menghindari terjadinya penumpukan atau kekurangan stok dikemudian hari. Sekalipun begitu, jumlah ini dapat diganti oleh pengguna. 

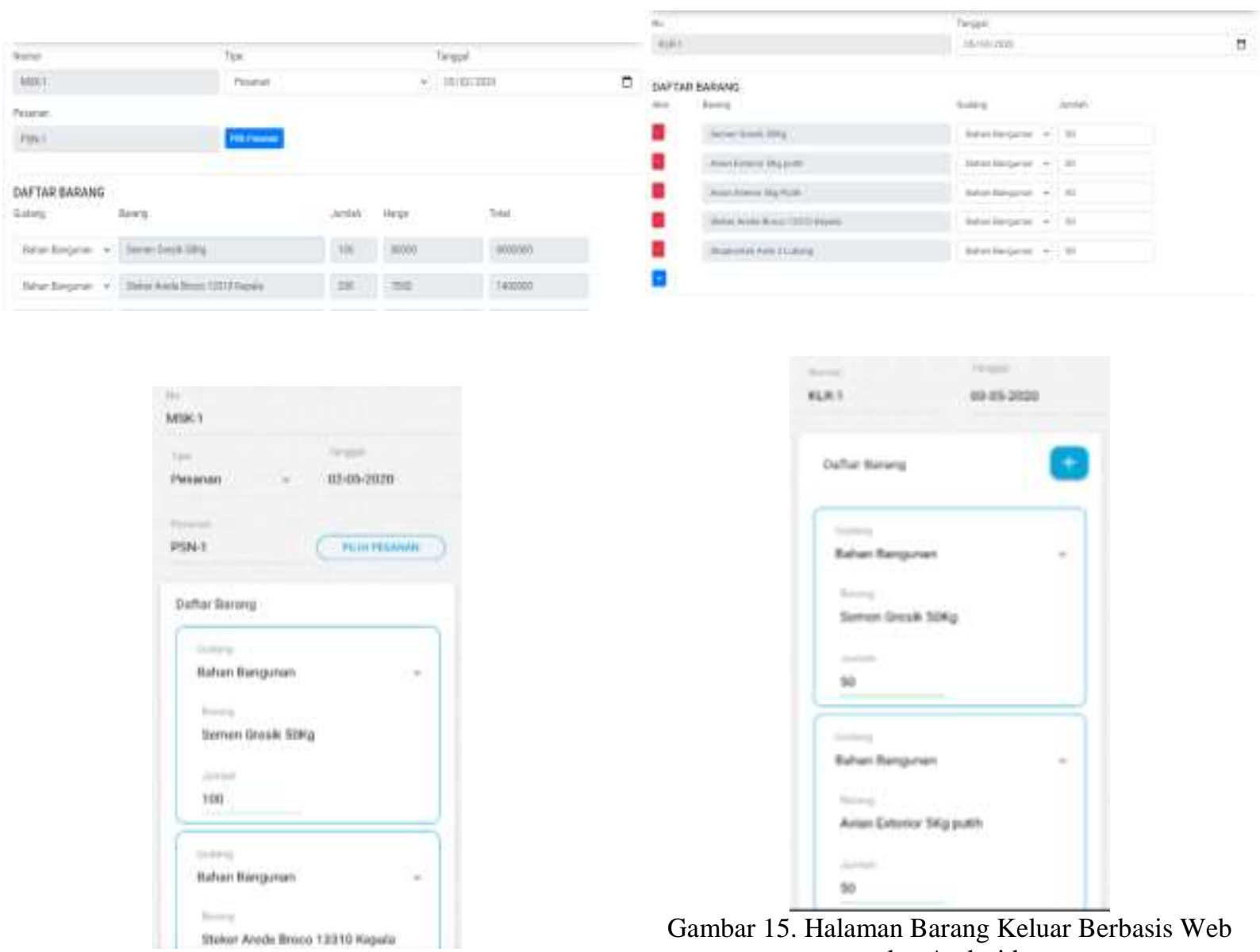

Gambar 14. Halaman Barang Masuk Berbasis Web dan Android

Pada Gambar 14 menunjukkan halaman barang masuk. Pada halaman ini pengguna mengisi data barang masuk berupa tanggal, tipe, tanggal, gudang, dan nomor pesanan atau nomor retur. Tipe digunakan untuk memilih asal barang masuk yaitu pesanan barang atau retur barang. Ketika pengguna memilih data pesanan, secara otomatis daftar barang terisi sesuai dengan data pada pesanan kemudian pengguna memilih data gudang pada setiap barang yang digunakan sebagai tempat penyimpanan barang tersebut. Aktivitas pada halaman ini mempengaruhi jumlah stok barang [14][18]. Dengan adanya fitur ini, maka data stok barang selalu update.

Selanjutnya untuk mencatat barang keluar dapat dilakukan pada halaman barang keluar. Halaman ini ditunjukkan pada Gambar 15. Pengguna mengisi data barang keluar berupa tanggal, barang, gudang, dan jumlah barang [14][18]. Aktivitas pada halaman ini mengurangi stok barang pada gudang yang dipilih. Barang keluar yang dimaksud adalah barang yang keluar dari gudang untuk disimpan di toko. Bukan barang yang habis terjual.

Gambar 16. Halaman Retur Barang Berbasis Web dan Android 
Sebelum penggunaan sistem, tidak pernah dilakukan pencatatan return barang. Jika barang datang dan tidak sesuai, kepala gudang hanya mencoret jumlah dan total harga dalam nota yang dibawa pengiriman. Hal ini tentu tidak baik karena selain merusak nota juga dinilai mengurangi kevalidan bukti penerimaan barang. Halaman ini ditunjukkan pada Gambar 16.

Selanjutnya adalah halaman untuk menampilkan daftar stock opname beserta data stock opname berupa nomor, tanggal, dan gudang. Pengguna dapat mencari berdasarkan nomor dengan mengetikkan nomor dibagian pencarian (web) sedangkan untuk android harus menekan ikon pencarian dahulu lalu menginputkan nomor. Pengguna juga dapat mengedit atau menghapus dengan menekan tombol edit atau hapus (web) sedangkan untuk android pengguna harus menekan dan tahan salah satu data stock opname kemudian akan muncul tombol detail, edit dan hapus. Pengguna dapat menambahkan data stock opname dengan menekan tombol tambah (plus). Gambar 17 menampilkan antarmuka halaman stock opname.
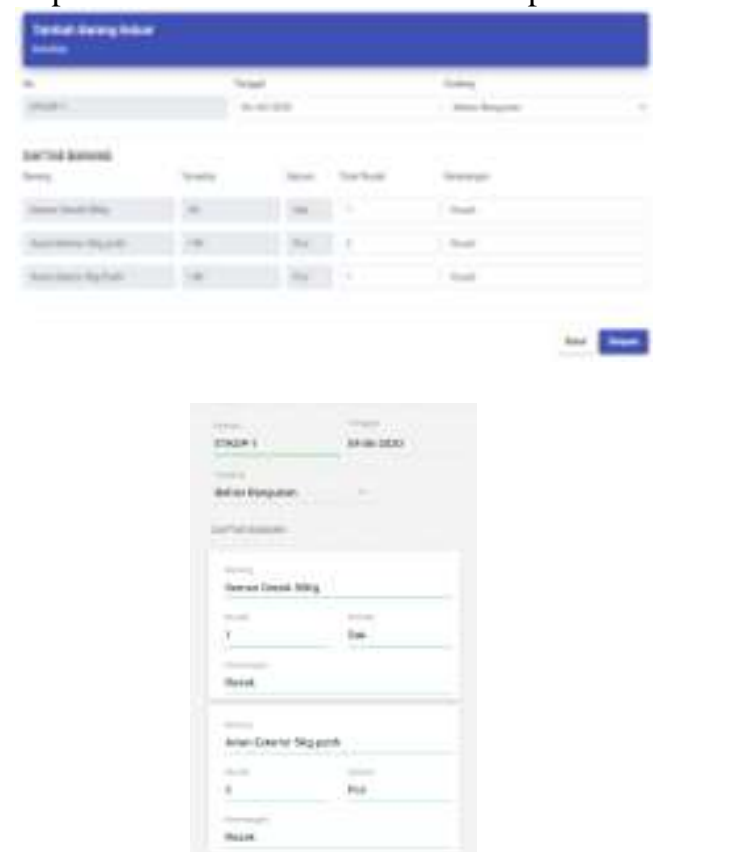

Gambar 17. Halaman Stock Opname

Pada form stock opname pengguna mengisi data stock opname berupa tanggal, gudang, dan jumlah barang rusak. Daftar barang menampilkan seluruh data barang yang terdapat pada gudang dan jumlah stok yang tersedia. Tombol simpan untuk menyimpan data stock opname.

Halaman kartu stok menampilkan rekap keluar dan masuknya daftar barang. Pengguna dapat mencari berdasarkan kode barang dengan mengetikkan kode barang dibagian pencarian (web) sedangkan untuk android harus menekan ikon pencarian dahulu lalu menginputkan kode barang. Pengguna juga dapat memilih salah satu barang untuk mengetahui kartu stok dari barang tersebut dengan menekan kode barang (web) sedangkan untuk android pengguna menekan data salah satu barang kemudian akan diarahkan ke form kartu stok. Gambar 18 menampilkan halaman kartu stok.

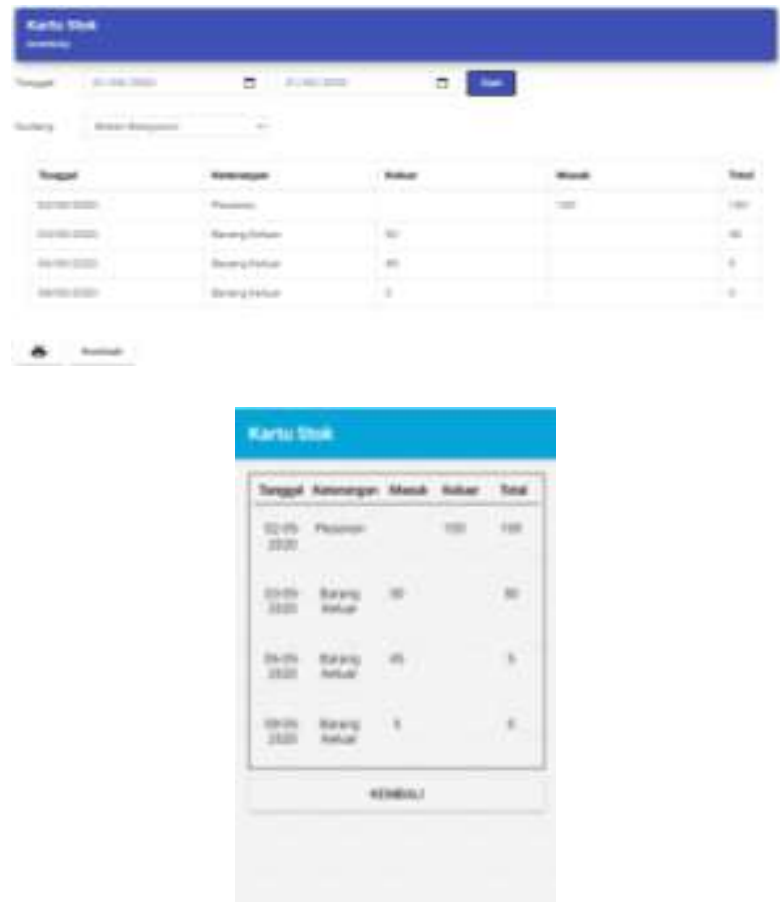

Gambar 18. Halaman Kartu Stok

Pada form kartu stok pengguna mengisi data kartu stok berupa tanggal awal, tanggal akhir dan gudang. Tombol cari untuk memproses data tersebut. Pengguna akan mendapatkan respon berupa data kartu stok yang berupa tanggal, keterangan, jumlah barang keluar, jumlah barang masuk, dan stok barang pada tanggal tertentu. Gambar 19 menunjukkan contoh laporan kartu stok untuk barang Steker pada gudang bahan bangunan.

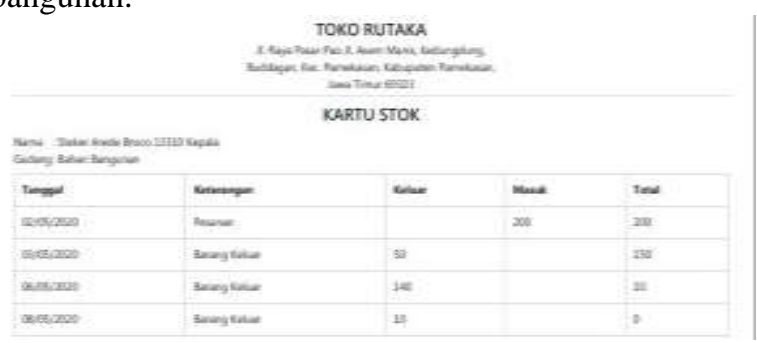

Gambar 19. Laporan kartu stok

Pengujian sistem dilakukan untuk mengetahui fungsi-fungsi dari sistem yang telah dibangun apakah berjalan dengan baik atau tidak dan dijadikan bahan untuk dievaluasi. Adapun metode pengujian sistem yang kami gunakan adalah Black Box Testing dengan menggunakan Boundary Value Analysis (BVA)[20]. Pengujian dilakukan dengan mencobakan sejumlah inputan pada sistem dengan hasil yang ditunjukkan pada Tabel 2 di bawah ini. 
Tabel 2. Rekap Hasil Pengujian BVA

\begin{tabular}{clc}
\hline No & Field & Persentase Keberhasilan \\
\hline 1 & Kode Barang & $100 \%$ \\
2 & Nama Barang & $100 \%$ \\
3 & Harga Beli & $100 \%$ \\
4 & Harga Jual & $100 \%$ \\
5 & Jumlah Pembelian & $100 \%$ \\
6 & Nama Pemasok & $100 \%$ \\
\hline & Rata - Rata & $100 \%$ \\
\hline
\end{tabular}

Pengujian sistem sudah $100 \%$ benar karena untuk inputan harga hanya bisa menginputkan angka, begitu juga dengan jumlah stok. Sedangkan untuk tanggal dan kode pemasok dibuat sesuai otomatis dari sistem.

Tabel 3. Inputan

\begin{tabular}{llll}
\hline Bulan & Permintaan & Peramalan & Error \\
\hline Januari & 2.000 & & \\
Februari & 3.960 & & \\
Maret & 2.000 & & \\
April & 2.200 & 2.653 & $20,6 \%$ \\
Mei & 1.920 & 2.720 & $41,7 \%$ \\
Juni & 1.840 & 2.040 & $10,9 \%$ \\
Juli & 1.840 & 1.987 & $8,0 \%$ \\
Agustus & 2.200 & 1.867 & $15,2 \%$ \\
September & 2.440 & 1.960 & $19,7 \%$ \\
Oktober & 1.920 & 2.160 & $12,5 \%$ \\
November & 1.680 & 2.187 & $30,2 \%$ \\
Desember & 1.840 & 2.013 & $9,4 \%$ \\
\hline \multicolumn{4}{c}{ Rata-Rata Error } \\
\hline
\end{tabular}

Untuk contoh pengujian dengan metode moving average dapat dilihat pada Tabel 3 dengan menggunakan data penjualan Semen Gresik. Sedangkan untuk rekap hasil ujicoba beberapa barang lainnya dapat dilihat pada Tabel 4. Tabel 4 menunjukkan bahwa metode moving average cukup bagus untuk melakukan peramalan pembelian barang dengan menggunakan data hasil penjualan di beberapa bulan sebelumnya.

Tabel 4. Rekap Hasil Ujicoba Moving Average

\begin{tabular}{lll}
\hline No & Field & Rata-rata Error \\
\hline 1 & Semen Gresik & $18.7 \%$ \\
2 & Semen Tiga Roda & $21 \%$ \\
3 & Besi Cor Ukuran 8 & $17.4 \%$ \\
4 & Besi Cor Ukuran 10 & $17.9 \%$ \\
5 & Stop Kontak Arde 2 Lubang & $27 \%$ \\
\hline
\end{tabular}

Setelah melakukan pengujian sistem, peneliti juga melakukan wawancara terhadap pemilik toko mengenai sistem yang telah dibangun. Berikut hasil dari wawancara yang telah dilakukan:

Apakah sistem yang dibangun mudah digunakan? Cukup mudah, namun karena kami belum terbiasa menggunakan aplikasi, kami masih sering lupa bagaimana alur dan cara menggunakannya

Apakah sistem ini dapat mempermudah transaksi yang terjadi di gudang? Ya, pencatatan barang masuk, barang keluar dapat dengan mudah dilakukan. Stok yang tersedia di setiap gudang juga dapat diketahui secara cepat. Jika dibandingkan dengan sistem yang digunakan saat ini, pencatatan barang dan keluar di catat pada kartu stok dan menjumlahkan atau mengurangi dengan stok saat ini baru dapat diketahui jumlah stok yang tersedia, sehingga kami mengalami kesulitan saat ingin mengetahui jumlah stok yang tersedia berdasarkan tanggal tertentu. Laporan-laporan yang disediakan di sistem ini lebih mudah digunakan dan dilakukan secara cepat serta dapat disesuaikan berdasar periode tertentu.

Apakah sistem ini mempermudah manajemen keuangan? Ya, transaksi-transaksi di toko misalnya penjualan, pendapatan, pengeluaran pada toko dapat di ketahui dan didokumentasikan dengan rapi. Tidak perlu menghitung jumlah nota penjualan untuk mengetahui hasil penjualan dan barang apa saja yang terjual hari ini. Laporan-laporan yang disediakan sudah cukup untuk memenuhi kebutuhan pada toko. Pembuatan laporan penjualan barang, arus kas, dan laba rugi dapat dilakukan dengan cepat.

\section{KESIMPULAN}

Metode pengembangan sistem informasi manajemen inventori pada penelitian ini menggunakan Metode Agile Software Development jenis Extreme Programming (XP). Rancangan sistem (planning) dibangun sesuai dengan hasil wawancara dan observasi dilapangan. Selain mengubah sistem manual menjadi terkomputerisasi, hasil obsservasi juga menunjukkan adanya kebutuhan akan peramalan dengan menggunakan Metode Moving Average untuk mengatasi masalah kelebihan dan kekurangan stok yang ada di gudang. Hasil planning ini kemudian diwujudkan dalam bentuk UML (design) untuk memudahkan implementasi ke dalam bahasa pemograman sesuai dengan konsep yang diperoleh pada proses planning. Pada proses coding, setiap bagian sistem selalu diujicobakan (testing) kepada pengguna dan langsung melakukan revisi jika dirasa tidak sesuai. Proses coding dan testing terjadi berulang sampai di sistem yang dibuat sesuai dengan kebutuhan pengguna yaitu pemilik toko. Hal ini karena metode Extreme Programming (XP) lebih mengutamakan untuk memenuhi kebutuhan pengguna.

Penerapan peramalan dengan Moving Average dapat mengatasi permasalahan yang dialami pengguna yaitu untuk mengetahui stok barang secara tepat dan cepat. Selain itu dapat membantu menghindari penumpukan dan kekurangan stok dengan menerapkan fitur peramalan dalam sistem.

Untuk pengembangan selanjutnya, sistem informasi manajemen inventori ini bisa diintegrasikan dengan menambahkan sistem informasi penjualan dan sistem informasi keuangan. Sistem yang terintegrasi memudahkan pemiliki toko untuk mengetahui keadaan tokonya tidak hanya dilihat dari stok barang tapi juga hasil penjualan dan kondisi keuangan termasuk laba rugi. Selain itu, untuk mengurangi error, dapat menggunakan metode peramalan pembelian barang dengan memperhatikan pola pembelian yang 
mengalami naik turun, seperti saat musim proyek, biasanya jumlah permintaan bahan bangunan mengalami peningkatan.

\section{DAFTAR PUSTAKA}

[1] N. Burhan and A. M. Mamonto, "Sistem Informasi Penjualan dan Persediaan Barang Dagang Pada Perusahaan Hakasima Kota ternate," J. Ilm. Ilk. - Ilmu Komput. Inform., vol. 1, no. 1, pp. 39-49, 2018, doi: 10.47324/ilkominfo.v1i1.6.

[2] Noviani and P. A. Wijaya, Siklus Akuntasi Perusahaan Dagang, I. Magelang: Tidar Media, 2020.

[3] K. R. Karongkong, V. Ilat, and V. Z. Tirayoh, "Penerapan Akuntansi Persediaan Barang Dagang Pada Ud. Muda-Mudi Tolitoli," Going Concern J. Ris. Akunt., vol. 13, no. 2, pp. 4656, 2018, doi: 10.32400/gc.13.02.19082.2018.

[4] R. Rachman, "Penerapan Metode Moving Average Dan Exponential Smoothing Pada Peramalan Produksi Industri Garment," $J$. Inform., vol. 5, no. 2, pp. 211-220, 2018, doi: 10.31311/ji.v5i2.3309.

[5] N. Hudaningsih et al., "Perbandingan Peramalan Penjualan Produk Aknil Pt . Sunthi Sepuri Mengguanakan Metode Single Moving Average Dan Single Exponential Smooting," J. JINTEKS, vol. 2, no. 1, pp. 15-22, 2020.

[6] I. K. Sriwana, M. L. Christia, E. Ellytasia, and G. Chandiawan, "Perancangan Sistem Informasi Inventory Pt. Abc," J. Ilm. Tek. Ind., vol. 6, no. 1, pp. 9-19, 2019, doi: 10.24912/jitiuntar.v6i1.3019.

[7] H. Agusvianto, "Sistem Informasi Inventori Gudang Untuk Mengontrol Persediaan Barang Pada Gudang Studi Kasus: PT.Alaisys Sidoarjo," J. Inf. Eng. Educ. Technol., vol. 1, no. 1, p. 40, 2017, doi: 10.26740/jieet.v1n1.p40-46.

[8] Y. Siyamto, "Perancangan Aplikasi Easy Inventory Untuk Peningkatan Efisiensi Inventory UMKM Kota Batam," vol. 7, no. 1, pp. 18-22, 2019.

[9] A. E. Syaputra, "Aplikasi Manajemen Inventory Berbasis Mobile," J. Inf. Technol., vol. 6, no. 1, pp. 23-32, 2018.

[10] S. Sabarudin and S. A. Shar, "Pengembangan sistem informasi inventory berbasis web dan mobile pada perusahaan transitco," vol. 14, no. 1, pp. 63-72, 2020.

[11] N. P. Dewi and I. Listiowarni, "Peramalan Harga Bahan Proyek Menggunakan Metode Least Square (Studi Kasus: CV Rizky Mulya)," J. Teknol. Inform., vol. 2, no. 1, pp. 27-33, 2019.

[12] F. N. Rofiq, "Implementasi RESTful Web Service untuk Sistem Penghitungan Suara
Secara Cepat pada Pilkada Implementation of Restful Web Servicefor Quick Count System of MayorElection," EKSPLORA Inform., vol. 6, no. 2, pp. 159-168, 2019.

[13] S. Sibagariang, "Penerapan Web Service Pada Perpustakaan Berbasis Android," J. Maharjana Inf., vol. 1, no. 2, pp. 8-11, 2016, [Online]. Available: http://e-journal.sarimutiara.ac.id/index.php/7/article/view/172.

[14] S. Zalukhu and I. Handriani, "Analisa dan Perancangan Aplikasi Sistem Inventory ( Studi Kasus : Pt . Cakra Medika Utama ),"Jsai, vol. 2, no. 1, pp. 116-122, 2019.

[15] R. Baxter, Software engineering is software engineering. 2006.

[16] A. Hendini, "Pemodelan Uml Sistem Informasi Monitoring Penjualan Dan Stok Barang," J. Khatulistiwa Inform., vol. 2, no. 9, pp. 107-116, 2016, doi: 10.1017/CBO9781107415324.004

[17] E. W. Fridayanthie and T. Mahdiati, "Rancang Bangun Sistem Informasi Permintaan ATK Berbasis Intranet (Studi Kasus: Kejaksaan Negeri Rangkasbitung)," J. Khatulistiwa Inform., vol. 4, no. 2, pp. 126-138, 2016.

[18] F. Darnis, "Mobile Application for Inventory Control in a Minimart," ComTech Comput. Math. Eng. Appl., vol. 8, no. 2, p. 101, 2017, doi: $10.21512 /$ comtech.v8i2.3755.

[19] N. P. Dewi and I. Listiowarni, "Implementasi Game Based Learning pada Pembelajaran Bahasa Inggris," J. RESTI (Rekayasa Sist. dan Teknol. Informasi), vol. 3, no. 2, pp. 124-130, 2019, doi: 10.29207/resti.v3i2.885.

[20] T. S. Jaya, "Pengujian Aplikasi dengan Metode Blackbox Testing Boundary Value Analysis (Studi Kasus: Kantor Digital Politeknik Negeri Lampung)," J. Inform. Pengemb. IT, vol. 3, no. 2, pp. 45-46, 2018, [Online].

Available: http://www.ejournal.poltektegal.ac.id/index.ph p/informatika/article/view/647/640. 